$\checkmark$ Research Square

\title{
Combined CTP- IGF-1 Score: A New Score for Assessment of Disease Severity in HCV Related Liver Cirrhosis
}

\section{Elsayed Ghannam}

Mansoura University

\section{Salah Rozaik}

Mansoura University Faculty of Medicine

\section{Ramy Hasan Agwa}

Mansoura University Faculty of Medicine

Ahmed Marwan

Mansoura University Faculty of Medicine

Mervat El-Sayed Mashaly

Mansoura University Faculty of Medicine

Mohamed Mofreh Salem

Mansoura University Faculty of Medicine

Abeer Saad El zekred

Mansoura University Faculty of Medicine

Ahmed Saleh ( $\square$ drahmedsaleh1981@gmail.com )

Mansoura University Faculty of Medicine https://orcid.org/0000-0001-8028-1997

\section{Research Article}

Keywords: IGF-1, Child-Turcotte-Pugh

Posted Date: January 3rd, 2022

DOI: https://doi.org/10.21203/rs.3.rs-1216787/v1

License: (c) (1) This work is licensed under a Creative Commons Attribution 4.0 International License. Read Full License 


\section{Abstract}

Background: Liver is the largest endocrine organ in the body. It is a key organ in insulin mediated metabolism, growth hormone and insulin like growth factors (IGF) pathway. Liver cirrhosis is the end result of many chronic diseases including hepatitis $C$ virus infection. Child-Turcotte-Pugh (CTP) score is the standard used in assessment of hepatic reserve but it has its drawbacks in the form of subjective variables, hepatic encephalopathy and ascites. The aim of this work is to assess IGF-1 in patients with liver cirrhosis, correlate it with CTP score and assess value of modified combined CTP-IGF-1 score.

Patients and Methods: 170 patients with CLD (liver cirrhosis) and 72 healthy controls in the study groups were enrolled in the study. All patients were subjected to thorough history, clinical examination and laboratory assessment. IGF-1 was measured and all patients were evaluated using CTP and CTP-IGF-1 scores.

Results: IGF1 showed highly significant low values in the study group in comparison to controls (42.15 \pm 27.976 and $66.31 \pm 33.084 \mathrm{ng} / \mathrm{ml}$ respectively, $\mathrm{p}<0.001)$. It showed also highly significant negative correlation to CTP score in the study group $(p<0.001)$ with progressive decrements with CTP score stage progression where IGF1 levels were $48.32 \pm 28.611,40.28 \pm 25.869$ and $18.80 \pm 15.953 \mathrm{ng} / \mathrm{ml}$ (mean \pm standard deviation) in relation to CTP score groups A, B and C respectively ( $p$ value $<0.001$ ). The combined CTP-IGF-1 score in comparison to the classic CTP score showed improved area under curve ( 0.848 and 0.854$)$, sensitivity $(71.2 \%$ and $88 \%)$, negative predictive value ( $41.7 \%$ and $53.7 \%)$, false negative results (49 and 19$)$ and accuracy $(75.73 \%$ and $83.98 \%)$ but decreased specificity $(97.22 \%$ and $61.1 \%)$, positive predictive value (99.2\% and $91.5 \%$ ) and higher false positive results (1 and 14 ) respectively.

Conclusion: IGF-1 show progressive decrements with progression of liver cirrhosis and is negatively correlated with CTP score. Addition of IGF-1 to CTP score to formulate combined score improves the AUC, sensitivity, negative predictive value and the accuracy of CTP score and decreases the false negative results.

\section{Introduction}

Liver is a major metabolic organ in the body, involved in glucose, lipid and hormone metabolism. Liver is the largest endocrine organ in the body and it is a key organ in insulin-mediated metabolism and insulin like growth factors (IGFs) pathway including insulin like growth factor-1 (IGF-1), insulin like growth fctor-2 (IGF-2) and their binding proteins (IGFBPs) [1, 2]. In mammals; IGF-1 is related to post-natal growth mediated by growth hormone and IGF-2 is related to stimulation of foetal and placental growths that are less dependent on growth hormone [3]. Growth factors produced in the liver, including IGF-1 and IGF-2, affect hepatocytes proliferation, differentiation and apoptosis [4].

Liver cirrhosis is the end result of many chronic liver diseases (CLD) including chronic viral hepatitis, alcoholic liver diseases and non-alcoholic fatty liver disease. Liver cirrhosis is characterised by 
replacement of liver tissue by fibrotic tissue, necrosis and regenerating nodules [5, 6]. Liver cirrhosis is associated with IGF pathway changes that result in progressive hepatocellular function deterioration [5]. Patients with chronic liver disease show reductions in hepatic response to growth hormone resulting in elevated growth hormone levels and decreased IGFs levels. This leads to clinical features of IGF1 deficiency [6, 7]. Negative correlations between IGF1 and International Normalization Ratio (INR) [8] Model for End stage Liver Disease (MELD) score [8] and splenic size [9] was reported, and correlation was positive with serum albumin levels $[8,9]$. Reduced IGF1 levels were reported in cases with hepatocellular carcinoma (HCC) in comparison to cirrhotics and healthy controls [10]. The Child-Turcotte-Pugh (CTP) scores is the system used to assess hepatic reserve, overall survival and treatment outcomes in patients with chronic liver diseases $[11,12]$.

Aim of the study The aim of this work is to assess IGF1 levels in patients with liver cirrhosis in comparison to healthy controls and correlate IGF1 levels with CTP score in those patients.

\section{Patients And Methods}

This is a case-control study that included 170 patients with CLD and 72 healthy controls. CLD (liver cirrhosis) in the study group was caused by chronic hepatitis C virus (HCV) infection. Liver cirrhosis was identified by clinical assessment, abdominal ultrasonography (US), and laboratory assessment.

All subjects in the study were assessed by a thorough history and clinical examination, including residency (urban or rural), smoking history, history of chronic diseases including diabetes mellitus and hypertension, history of previous surgical or dental procedures, and history of anti-bilharzial treatment. Laboratory investigations included CBC, INR, ALT, AST, serum albumin, serum bilirubin, serum creatinine, alpha feto protein and random blood glucose.

\section{Igf-1 Assessment}

Peripheral venous blood samples (3-5 mL) were collected, anticoagulated by ethylenediaminetetraacetic acid (EDTA), and centrifuged at $4^{\circ} \mathrm{C}$ for 15 minutes at 3000 RPM. The plasma samples were then extracted, aliquoted, and snap-frozen at $-20^{\circ} \mathrm{C}$ until analysis.IGF- 1 was tested by an enzyme-linked immunosorbent assay (ELISA) according to the manufacturer's directions (Quantikine Human IGF-1 ELISA Kit; R \& D Systems, Minneapolis, MN). In the MD Anderson validation cohort, plasma IGF-1 was tested at a Clinical Laboratory Improvement Amendments (CLIA)-certified facility that uses Luminex microsphere technology by Myriad Laboratories (Austin, Texas).

CTP and combined CTP-IGF-1 scores were calculated using the parameters shown in Table 1 and 2 respectively stratified as class A (5-6), B (7-9) or C (10-15) [13]. 
Table 1

shows the parameters of the CTP score [13].

\begin{tabular}{|llll|}
\hline Measure & $\begin{array}{l}\mathbf{1} \\
\text { point }\end{array}$ & $\mathbf{2}$ points & 3 points \\
\hline Serum total bilirubin $(\mathrm{mg} / \mathrm{dl})$ & $<2$ & $2-3$ & $>3$ \\
Serum albumin (gm/L) & $>3.5$ & $2.8-3.5$ & $<2.8$ \\
$\begin{array}{l}\text { Prothrombin time prolongation } \\
\text { (seconds) OR }\end{array}$ & $<4$ & $4-6$ & $>6$ \\
INR & $<1.7$ & $1.7-2.3$ & $>2.3$ \\
Ascites & None & $\begin{array}{l}\text { Mild (or treatment } \\
\text { responsive) }\end{array}$ & $\begin{array}{l}\text { Moderate to severe (or } \\
\text { refractory) }\end{array}$ \\
\hline Encephalopathy & None & Grade I-II & Grade III-IV \\
\hline
\end{tabular}

Table 2

shows the combined CTP-IGF-1 score

\begin{tabular}{|llll|}
\hline Measure & 1 point & 2 points & 3 points \\
\hline Serum total bilirubin $(\mathrm{mg} / \mathrm{dl})$ & $<2$ & $2-3$ & $>3$ \\
\hline Serum albumin $(\mathrm{gm} / \mathrm{L})$ & $>3.5$ & $2.8-3.5$ & $<2.8$ \\
\hline Prothrombin time prolongation (seconds) OR & $<4$ & $4-6$ & $>6$ \\
INR & $<1.7$ & $1.7-2.3$ & $>2.3$ \\
\hline IGF & $<25$ & $25-50$ & $>50$ \\
\hline
\end{tabular}

\section{Statistical analysis}

Data were fed to the computer and analyzed using IBM SPSS Corp. Released 2013. IBM SPSS Statistics for Windows, Version 22.0. Armonk, NY: IBM Corp. Qualitative data were described using number and percent. Quantitative data were described using median (minimum and maximum) \& inter quartile range for non-parametric data and mean, standard deviation for parametric data after testing normality using Kolmogrov-Smirnov test. Significance of the obtained results was judged at the (0.05) level. Chi-Square test, Fischer Exact test \& Monte Carlo test for comparison of 2 or more groups for qualitative variables. Stewart -Maxwell test was used to compare follow up periods for categorical variables with more than 2 categories. Student t-test was used to compare 2 independent groups, Paired t test \& Repeated Measures ANOVA to compare between studied periods with post Hoc Tukey test for parametric variables. MannWhitney $\mathrm{U}$ test was used to compare 2 independent groups, Wilcoxon signed Rank test \& Freidmann test were used to compare studied periods for non-parametric variables.

\section{Results}


This study included 170 patients with chronic HCV related liver cirrhosis and 72 healthy controls. According to CTP score; this study included $93 \mathrm{~A}, 57 \mathrm{~B}$ and $20 \mathrm{C}$. The demographic data of the study group in comparison to the controls showed that there was no significant difference between both groups regarding residency, occupation, smoking history, hypertension history and surgical or dental procedures. The age of the study group is older than the controls (controls $41.50 \pm 10.961$ years, study group $56.96 \pm$ 6.813 years, $p<0.001$ ) and most of the cases were males (controls $50.0 \%$, study group $72.9 \%, p 0.007$ ). Diabetes mellitus (controls $0.0 \%$, study group $28.2 \%, \mathrm{p}<0.001$ ) and history of anti-bilharzial treatment (controls $30.6 \%$ oral and $5.6 \%$ injection, study group $51.8 \%$ oral and $29.4 \%$ injection, $p<0.001$ ) were significantly higher in the study group in comparison to controls (table 3 ).

Regarding the laboratory investigations of the study group in comparison to controls, IGF-1 showed highly significant low values in the study group in comparison to controls (42.15 27.976 and 66.31 $33.084 \mathrm{ng} / \mathrm{ml}$, respectively, p 0.001). Other laboratory investigations showed significantly lower haemoglobin $(12.25 \pm 1.792,13.32 \pm 1.649$, p 0.001), platelets $(115.12 \pm 66.981,215.19 \pm 60.221$, p value $<0.001)$, serum albumin $(3.26 \pm 0.615,4.37 \pm 0.458, p<0.001)$ in the study group in comparison to controls in a respective manner and significantly higher white blood cells $(6.38 \pm 12.816,6.13 \pm 1.816, p$ 0.015), random blood glucose (127.08 $\pm 54.142,97.97 \pm 14.812, p 0.001)$, AST $(74.51 \pm 39.585,50.03 \pm$ $31.661,0<0.001)$, serum bilirubin $(1.88 \pm 1.679,0.78 \pm 0.247, p<0.001)$, INR $(1.25 \pm 0.220,1.07 \pm 0.095, p$ $<0.001)$ and alpha feto protein $(356.34 \pm 1093.41,4.85 \pm 6.04, p<0.001)$ in the study group in comparison to controls in a respective manner (Table 4 ).

Assessment of the levels of IGF-1 in relation to CTP score in the study group showed that IGF1 levels were $48.32 \pm 28.611,40.28 \pm 25.869$ and $18.80 \pm 15.953 \mathrm{ng} / \mathrm{ml}$ (mean \pm standard deviation) in relation to CTP score groups A, B and C respectively ( $p$ value $<0.001$ ) (Table 4).

Correlation between IGF-1 and CTP score in the study group using Spearman correlation coefficient revealed that there is highly significant negative correlation between IGF-1 and CTP score in the study group $(\mathrm{p}<0.001)$ (Table 5).

Comparison of IGF-1, CTP score and combined CTP-IGF-1 score in differentiating normal liver in one hand from liver cirrhosis in the other hand showed that the area under the curve was $0.718,0.848$ and 0.854 , and the diagnostic point was $55.5 \mathrm{ng} / \mathrm{ml}, 5.5$ and 4.5 , sensitivity $71.2 \%, 72.2 \%$ and $88.8 \%$, specificity $61.1 \%, 97.22 \%$ and $91.5 \%$, negative predictive value $31.0 \%, 41.7 \%$ and $53.7 \%$, and accuracy $69.42 \%$, $75.73 \%$ and $83.98 \%$ for IGF-1, CTP-IGF-1 score respectively (Table 7 and figure 1 ). 
Table 3

Demographic characteristics and medical history of the studied patients in comparison to controls

\begin{tabular}{|c|c|c|c|c|c|}
\hline & & Control group $(n=72)$ & $\begin{array}{l}\text { Study group } \\
(n=170)\end{array}$ & $95 \% \mathrm{Cl}$ & p \\
\hline \multicolumn{2}{|l|}{ Age (years) } & $49.50 \pm 10.961$ & $53.96 \pm 6.813$ & $-19.3,-11.6$ & 0.061 \\
\hline \multirow[t]{2}{*}{ Gender } & Male & $50.0 \%(36)$ & $72.9 \%(124)$ & \multirow[t]{2}{*}{$0.05,0.41$} & \multirow[t]{2}{*}{0.007} \\
\hline & Female & $50.0 \%(36)$ & $27.1 \%(46)$ & & \\
\hline \multirow[t]{2}{*}{ Residency } & Rural & $94.4 \%(68)$ & $97.1 \%(165)$ & \multirow[t]{2}{*}{$-0.05,0.11$} & \multirow[t]{2}{*}{0.608} \\
\hline & Urban & $5.6 \%(4)$ & $2.9 \%(5)$ & & \\
\hline \multirow[t]{3}{*}{ Occupation } & Employee & $13.9 \%(10)$ & $25.9 \%(44)$ & \multirow[t]{3}{*}{-} & \multirow[t]{3}{*}{0.131} \\
\hline & Housewife & $41.7 \%(30)$ & $27.1 \%(46)$ & & \\
\hline & $\begin{array}{l}\text { Manual } \\
\text { worker }\end{array}$ & $44.4 \%(32)$ & $47.1 \%(80)$ & & \\
\hline \multirow[t]{3}{*}{ Smoking } & No & $66.7 \%(48)$ & $70.4 \%(119)$ & \multirow[t]{3}{*}{-} & \multirow[t]{3}{*}{0.835} \\
\hline & Smoker & $27.8 \%(20)$ & $26.0 \%(44)$ & & \\
\hline & Ex-smoker & $5.6 \%(4)$ & $3.6 \%(6)$ & & \\
\hline \multicolumn{2}{|c|}{ History of DM } & $0 \%(0)$ & $28.2 \%(48)$ & $0.22,0.35$ & 0.001 \\
\hline \multicolumn{2}{|c|}{ History of HTN } & $8.3 \%(6)$ & $14.1 \%(24)$ & $-0.05,0.16$ & 0.428 \\
\hline \multicolumn{2}{|c|}{ History of Operation } & $44.4 \%(28)$ & $53.5 \%(91)$ & $-0.03,0.32$ & 0.322 \\
\hline \multicolumn{2}{|c|}{ History of Dental } & $72.2 \%(52)$ & $75.3 \%(128)$ & $-0.13,0.19$ & 0.700 \\
\hline \multirow{3}{*}{$\begin{array}{l}\text { History of } \\
\text { Anti- } \\
\text { bilharzial }\end{array}$} & None & $63.9 \%(46)$ & $18.8 \%(32)$ & \multirow[t]{3}{*}{-} & \multirow[t]{3}{*}{$\nabla 0.001$} \\
\hline & Oral & $30.6 \%(22)$ & $51.8 \%(88)$ & & \\
\hline & Injection & $5.6 \%(4)$ & $29.4 \%(50)$ & & \\
\hline
\end{tabular}


Table 4

laboratory investigations of the studied patients in comparison to controls

\begin{tabular}{|c|c|c|c|c|}
\hline & Control group $(n=72)$ & $\begin{array}{l}\text { Study group } \\
(n=170)\end{array}$ & $95 \% \mathrm{Cl}$ & $P$ \\
\hline $\mathrm{Hb}$ & $13.32 \pm 1.649$ & $12.25 \pm 1.792$ & $0.45,1.68$ & 0.001 \\
\hline WBCs & $6.13 \pm 1.816$ & $6.38 \pm 12.816$ & $-2.29,1.77$ & 0.015 \\
\hline Platelets & $215.19 \pm 60.221$ & $115.12 \pm 66.981$ & $77.47,122.67$ & $\nabla 0.001$ \\
\hline Creatinine & $0.84 \pm 0.117$ & $0.96 \pm 0.535$ & $-0.21,-0.03$ & 0.064 \\
\hline RBS & $97.97 \pm 14.812$ & $127.08 \pm 54.142$ & $-38.80,-19.41$ & 0.001 \\
\hline IGF1 (ng/ml) & $66.31 \pm 33.084$ & $42.15 \pm 27.976$ & $12.24,36.06$ & 0.001 \\
\hline ALT & $58.40 \pm 50.082$ & $55.88 \pm 30.115$ & $-14.98,20.02$ & 0.291 \\
\hline AST & $50.03 \pm 31.661$ & $74.51 \pm 39.585$ & $-36.69,-12.29$ & $\nabla 0.001$ \\
\hline Albumin & $4.37 \pm 0.458$ & $3.26 \pm 0.615$ & $0.94,1.30$ & $\nabla 0.001$ \\
\hline Bilirubin & $0.78 \pm 0.247$ & $1.88 \pm 1.679$ & $-1.36,-0.83$ & 0.001 \\
\hline INR & $1.07 \pm 0.095$ & $1.25 \pm 0.220$ & $-0.23,-0.13$ & 0.001 \\
\hline AFP & $4.85 \pm 6.04$ & $356.34 \pm 1093.41$ & $-517.05,-185.93$ & 0.001 \\
\hline \multicolumn{5}{|c|}{$\begin{array}{l}\text { Data is expressed as mean and standard deviation or as percentage and frequency. } 95 \% \mathrm{Cl} \text { : } 95 \% \\
\text { confidence interval of the mean difference between both groups. P is significant when } ₫ 0.05, \mathrm{Hb} \text { : } \\
\text { hemoglobin, WBCs: white blood cells, RBS: random blood sugar, IGF1: insulin like growth factor } 1 \text {, } \\
\text { ALT: alanine transaminase, AST: aspartate transaminase, INR: international normalized ratio, AFP: } \\
\text { alpha feto protein. }\end{array}$} \\
\hline
\end{tabular}

Table 5

Assessment of IGF-1 levels in study group based on CTP score groups

\begin{tabular}{|c|c|c|c|c|}
\hline & CTP A $(n=93)$ & CTP B $(n=57)$ & CTP C $(n=20)$ & $P$ \\
\hline IGF1 (ng/ml) & $48.32 \pm 28.611$ & $40.28 \pm 25.869$ & $18.80 \pm 15.953$ & $\nabla 0.001$ \\
\hline
\end{tabular}

Table 6

correlation between IGF-1 and CTP score

Spearman correlation coefficient

IGF-1 and CTP score

$\mathrm{P}$ is significant when $\otimes 0.05$, IGF1: insulin like growth factor-1, CTP: Child Turcot Pugh score 
Table 7: Comparison between IGF-1, CTP score and their combination in evaluation of liver cirrhosis.

\begin{tabular}{|llll|}
\hline & IGF-1 & CTP score & Combined \\
\hline Area Under Curve & 0.718 & 0.848 & 0.854 \\
\hline Diagnostic point & 55.50 & 5.5 & 4.5 \\
\hline Sensitivity & $71.2 \%$ & $71.2 \%$ & $88.8 \%$ \\
\hline Specificity & $61.1 \%$ & $97.22 \%$ & $61.1 \%$ \\
\hline Positive Predictive Value & $89.6 \%$ & $99.2 \%$ & $91.5 \%$ \\
\hline Negative Predictive Value & $31.0 \%$ & $41.7 \%$ & $53.7 \%$ \\
\hline False positive & 14 & 1 & 14 \\
\hline False negative & 49 & 49 & 19 \\
\hline Accuracy & $69.42 \%$ & $75.73 \%$ & $83.98 \%$ \\
\hline IGF1: Insulin like growth factor-1, CTP: Child Turcot Pugh Score \\
\hline
\end{tabular}

\section{Discussion}

Liver cirrhosis with or without the development of HCC are the end results of many liver diseases including non-alcoholic fatty liver diseases, chronic viral hepatitis, alcoholic liver diseases and autoimmune liver diseases $[5,6]$. Hepatitis $\mathrm{C}$ virus (HCV) infection is a major health problem in Egypt and anti-HCV antibodies were found to be positive in about $20 \%$ of Egyptian blood donors [15]. IGF system abnormalities were found in patients with liver cirrhosis. These abnormalities include growth hormone resistance and IGF-1 deficiencies with many metabolic abnormalities as a result [5].

Our study included 170 patients with HCV-related cirrhosis compared to 72 healthy controls. In comparison to the control group, most of the study group were males, which is related to the nature of the disease being more prevalent in males. Also, because the rate of HCV progression is slower in women, the rate of disease-related complications is higher in men $[15,16]$. In the study group, the history of diabetes mellitus was significantly higher ( $p$ 0.001) in the study group in comparison to controls. It was found that the risk of DM was four times higher in adults with HCV than in those without HCV [17]. HCV is linked to insulin resistance that is reported to show some improvement after HCV elimination $[18,19]$. A previous Egyptian study that included 396 chronic HCV infection patients found that a history of injectable antiBilharzial treatment was found in $32.3 \%$ of cases [20]. The current study shows that positive antibilharzial treatment is significantly higher in the study group in comparison to the controls. Anti-Bilharzial treatment may be linked to a risk of HCV infection through the parenteral route.

In our study, serum IGF-1 levels were found to be significantly ( $p$ value $0.001,95 \% \mathrm{Cl} 12.24,36.06$ ) lower in cases with HCV related liver cirrhosis in comparison to normal controls (42.15 27.976 and 66.31 
$33.084 \mathrm{ng} / \mathrm{ml}$, respectively). Similar results were found by Vyzantiadis and colleagues, who studied 40 patients with liver cirrhosis due to different etiologies and found that serum IGF-1 levels were significantly lower in cases with liver cirrhosis in comparison to 20 controls $(57.47 .0 \mathrm{ng} / \mathrm{mL}$ and $198.816 .3 \mathrm{ng} / \mathrm{mL}$, respectively, $p=0.0000001$ ) [22]. Raslan et al. studied 30 patients with chronic HCV infection (14 with cirrhosis) and 11 healthy controls and found that patients with liver cirrhosis had significantly lower IGF-1 levels ( $p$ value 0.001 ) [22]. The numbers of both cases and controls in these studies were low, and some of them had mixed etiologies of liver cirrhosis. Low serum IGF1 levels in patients with liver cirrhosis may be related to the impaired synthetic function of the liver with progressive deterioration with disease progression. Also, growth hormone receptors were found to show lower expression in the hepatic tissue of these patients $[23,24]$. Interestingly, we found that serum IGF-1 levels show progressive reduction with the progression of liver cirrhosis, indicated by higher CTP scores. Our study included 93 CTP A, 57 CTP B, and 20 CTP C patients with serum IGF-1 levels of $48.3228 .611,40.2825 .869$, and $18.8015 .953 \mathrm{ng} / \mathrm{ml}$, respectively ( $p$ value 0.001$)$. A highly significant negative correlation $(-0.318, p$ value 0.001$)$ was found between serum IGF-1 levels and CTP scores in our study group. Ronsoni and colleagues found that serum IGF-1 levels were negatively correlated with CTP score and MELD score in 74 patients with liver cirrhosis and significantly lower values of serum IGF-1 were observed in patients with higher CTP classes (P 0.05). [25]. Vyzantiadis and colleagues found that serum IGF-1 levels were significantly lower in cases with liver cirrhosis CTP B and C in comparison to cirrhotics with CTP A. Interestingly, comparison of the cases with CTP A $(n=26)$ in their study showed that there was no significant difference between viral and non-viral cirrhosis regarding serum IGF-1 levels, indicating that the cause of liver cirrhosis has a limited role and it is the stage of cirrhosis and CTP score that significantly affect serum IGF-1 levels [22]. Another study found that there was a statistically non-significant negative correlation between $\mathrm{HCV}$ viral load and serum IGF-1 levels [26]. Another study revealed that serum IGF-1 levels show progressive decrement with liver cirrhosis progression, namely higher CTP scores [27]. Of importance, Castro and colleagues found that serum IGF-1 levels returned to normal 6 months after orthotopic liver transplantation [28]. These data suggest that progression of liver cirrhosis is associated with a decrement in serum IGF-1 levels, probably due to progressive deterioration of hepatic synthetic functions and may be related to growth hormone insensitivity; these abnormalities may be corrected after liver transplantation.

Although CTP score has its drawbacks in the form of incorporation of two variables that are subjective, namely hepatic encephalopathy and ascites, it has been used for decades as the staging and prognostic method for cases of liver cirrhosis [29,30]. This had led to the development of ideas of processing of new scores that can avoid or at least decrease the effect of these subjective variables, hepatic encephalopathy and ascites. In our study; comparison of serum IGF-1, CTP score and combined CTP-IGF1 score (Table 6 and figure 1) in differentiating normal liver from liver cirrhosis showed that the addition of serum IGF-1 to CTP score in the form of combined score led to improved diagnostic profile of the classical CTP score in the form of improved AUC (0.848 and 0.854$)$, sensitivity $(71.2 \%$ and $88.8 \%)$, negative predictive value ( $41.7 \%$ and $53.7 \%$ ), false negative results (49 and 19$)$ and accuracy $(75.73 \%$ and $83.98 \%$ ) for CTP score and combined CTP-IGF-1 score respectively, but with some drawbacks in the 
form of reduced specificity (97.22\% and $61.1 \%)$, positive predictive value $(99.2 \%$ and $91.5 \%)$ and false positive results (1 and 14) for CTP score and combined CTP-IGF-1 score respectively.

\section{Conclusion}

IGF-1 showed progressive decrements with the progression of liver cirrhosis and is negatively correlated with the CTP score. The addition of IGF-1 to the CTP score to formulate a combined score improved the AUC, sensitivity, negative predictive value, and accuracy of the CTP score and decreased the false negative results.

\section{Declarations}

\section{Financial support and sponsorship}

Nil.

\section{Conflicts of interest}

There are no conflicts of interest.

\section{Ethics.}

The study protocol was investigated and approved by medical ethics research team, Faculty of Medicine in Mansoura University. Every case, after guaranteeing privacy, has given informed written consent. All methods were performed in accordance with relevant guidelines and regulations.

\section{References}

1. Postic C, Dentin R, Girard J. Role of the liver in the control of carbohydrate and lipid homeostasis. Diabetes Metab. 2004;30:398-408.

2. Liu Y, Guo W, Pu Z, Li X, Lei X, Yao J, Yang X. Developmental changes of Insulin-like growth factors in the liver and muscle of chick embryos. Poult Sci. 2016;95:1396-402.

3. Humbel RE. Insulin-like growth factors I and II. Eur J Biochem. 1990;190:445-62.

4. Adamek A, Kasprzak A. Insulin-Like Growth Factor (IGF) System in Liver Diseases. Int J Mol Sci. 2018;19(5):1308. doi:10.3390/ijms19051308. Published 2018 Apr 27.

5. Bonefeld K, Møller S. Insulin-like growth factor-I and the liver. Liver Int. 2011;31:911-9.

6. Puche JE, Castilla-Cortázar I. Human conditions of insulin-like growth factor-I (IGF-I) deficiency. J Transl Med. 2012;10:224.

7. Kasprzak A, Adamek A. The insulin-like growth factor (IGF) signaling axis and hepatitis $C$ virusassociated carcinogenesis (review). Int J Oncol. 2012;41:1919-31. 
8. Ronsoni MF, Lazzarotto C, Fayad L, Silva MC, Nogueira CL, Bazzo ML, Narciso-Schiavon JL, DantasCorrêa EB. Schiavon Lde, L. IGF-I and IGFBP-3 serum levels in patients hospitalized for complications of liver cirrhosis. Ann Hepatol. 2013;12:456-63.

9. Colako glu O, Ta, skiran B, Colako glu G, Kizilda $`$ g S, Ari Ozcan F, Unsal B. Serum insulin like growth factor-1 (IGF-1) and insulin like growth factor binding protein-3 (IGFBP-3) levels in liver cirrhosis. Turk J Gastroenterol. 2007;18:245-9.

10. Espelund U, Grønbæk H, Villadsen GE, Simonsen K, Vestergaard PF, Jørgensen JO, Flyvbjerg A, Vilstrup H, Frystyk J. The Circulating IGF System in Hepatocellular Carcinoma: The Impact of Liver Status and Treatment. Growth Horm. IGF Res. 2015;25:174-81.

11. Vauthey JN, Dixon E, Abdalla EK, Helton WS, Pawlik TM, Taouli B. Brouquet A and Adams RB. Pretreatment assessment of hepatocellular carcinoma: expert consensus statement. HPB. 2010;12:289-99.

12. Durand F, Valla D. Assessment of the prognosis of cirrhosis: Child-Pugh versus MELD. Journal of hepatology. 2005; 42 Suppl:S100-107.

13. Fischer SP, Bader AM, Sweitzer B. Preoperative evaluation. In: Miller RD, Eriksson LI, Wiener-Kronish JP, editors. Miller's anesthesia. 7th ed. Philadelphia: Churchil Livingstone Elsevier; 2009. p. 1027.

14. WHO. Hepatitis C, Fact sheet, $N^{\circ} 164$. 2015. Retreived from http://www.who.int/mediacentre/factsheets/fs164/en/, accessed 26 October 2020.

15. Davis GL, Alter MJ, El-Serag H, Poynard T, Jennings LW. Aging of hepatitis C virus (HCV)-infected persons in the United States: a multiple cohort model of HCV prevalence and disease progression. Gastroenterol. 2010;138:513-21.

16. Baden R, Rockstroh JK, Buti M. Natural history and management of hepatitis C: does sex play a role? J Infect Dis. 2014 Jul 15;209 Suppl 3:S81-5. doi: 10.1093/infdis/jiu057. PMID: 24966194.

17. Mehta SH, Brancati FL, Sulkowski MS, et al. Prevalence of type 2 diabetes mellitus among persons with hepatitis C virus infection in the United States. Ann Intern Med. 2000;133:592-9.

18. Sheikh MY, Choi J, Qadri I, et al. Hepatitis C virus infection: molecular pathways to metabolic syndrome. Hepatology. 2008;47:2127-33.

19. Delgado-Borrego A, Jordan $\mathrm{SH}$, Negre B, et al. Reduction of insulin resistance with effective clearance of hepatitis C infection: results from the HALT-C trial. Clin Gastroenterol Hepatol. 2010;8:458-462.

20. Abd El-Wahab W, Mikheal E, Sidkey A, Shatat F. HZ. Factors Associated with Hepatitis C Infection among Chronic HCV Egyptian Patients. Iran J Public Health. 2014;43(11):1510-8.

21. Vyzantiadis T, Theodoridou S, Giouleme O, Harsoulis P, Evgenidis N, Vyzantiadis A. Serum concentrations of insulin-like growth factor-I (IGF-I) in patients with liver cirrhosis. Hepatogastroenterology. 2003 May-Jun;50(51):814-6. PMID: 12828091.

22. Raslan HM, Elhosary Y, Ezzat WM, Rasheed EA, Rasheed MA. The potential role of insulin-like growth factor 1, insulin-like growth factor binding protein 3 and bone mineral density in patients with chronic hepatitis C virus in Cairo, Egypt. Trans R Soc Trop Med Hyg. 2010 Jun;104(6):429-32. doi: 10.1016/j.trstmh.2010.01.012. Epub 2010 Mar 1. PMID: 20189618. 
23. Shen XY, Holt RI, Miell JP, Justice S, Portmann B, Postel Vinay MC, Ross RJ. Cirrhotic liver expresses low levels of the full-length and truncated growth hormone receptors. J Clin Endocrinol Metab. 1998;83(7):2532-8.

24. Donaghy AJ, Delhanty PJ, Ho KK, Williams R, Baxter RC. Regulation of the growth hormone receptor/binding protein, insulin-like growth factor ternary complex system in human cirrhosis. $\mathrm{J}$ Hepatol. 2002;36(6):751-8.

25. Ronsoni MF, Lazzarotto C, Fayad L, Silva MC, Nogueira CL, Bazzo ML, Narciso-Schiavon JL, DantasCorrêa EB, Schiavon Lde L. IGF-I and IGFBP-3 serum levels in patients hospitalized for complications of liver cirrhosis. Ann Hepatol. 2013 May-Jun;12(3):456-63. PMID: 23619263.

26. Helaly GF, El-Afandy NM. Influence of HCV infection on insulin-like growth factor 1 and proinflammatory cytokines: association with risk for growth hormone resistance development. Egypt J Immunol. 2009;16(2):115-24. PMID: 22059359.

27. Colakoğlu O, Taşkiran B, Colakoğlu G, Kizildağ S, Ari Ozcan F, Unsal B. Serum insulin like growth factor-1 (IGF-1) and insulin like growth factor binding protein-3 (IGFBP-3) levels in liver cirrhosis. Turk J Gastroenterol. 2007 Dec;18(4):245-9. PMID: 18080921.

28. Castro GR, Coelho JC, Parolin MB, Matias JE, de Freitas AC. Insulin-like growth factor I correlates with MELD and returns to normal level after liver transplantation. Ann Transplant. 2013 Feb 12;18:57-62. doi: 10.12659/AOT.883819. PMID: 23792502.

29. Durand F, Valla D. Assessment of the prognosis of cirrhosis: Child-Pugh versus MELD. J Hepatol; 2005: 100-107.

30. Kok B, Abraldes JG. Child-pugh classification: time to abandon? Seminars Liver Dis; 39 (1) (2019), pp. $96-103,10.1055 / \mathrm{s}-0038-1676805$.

\section{Figures}




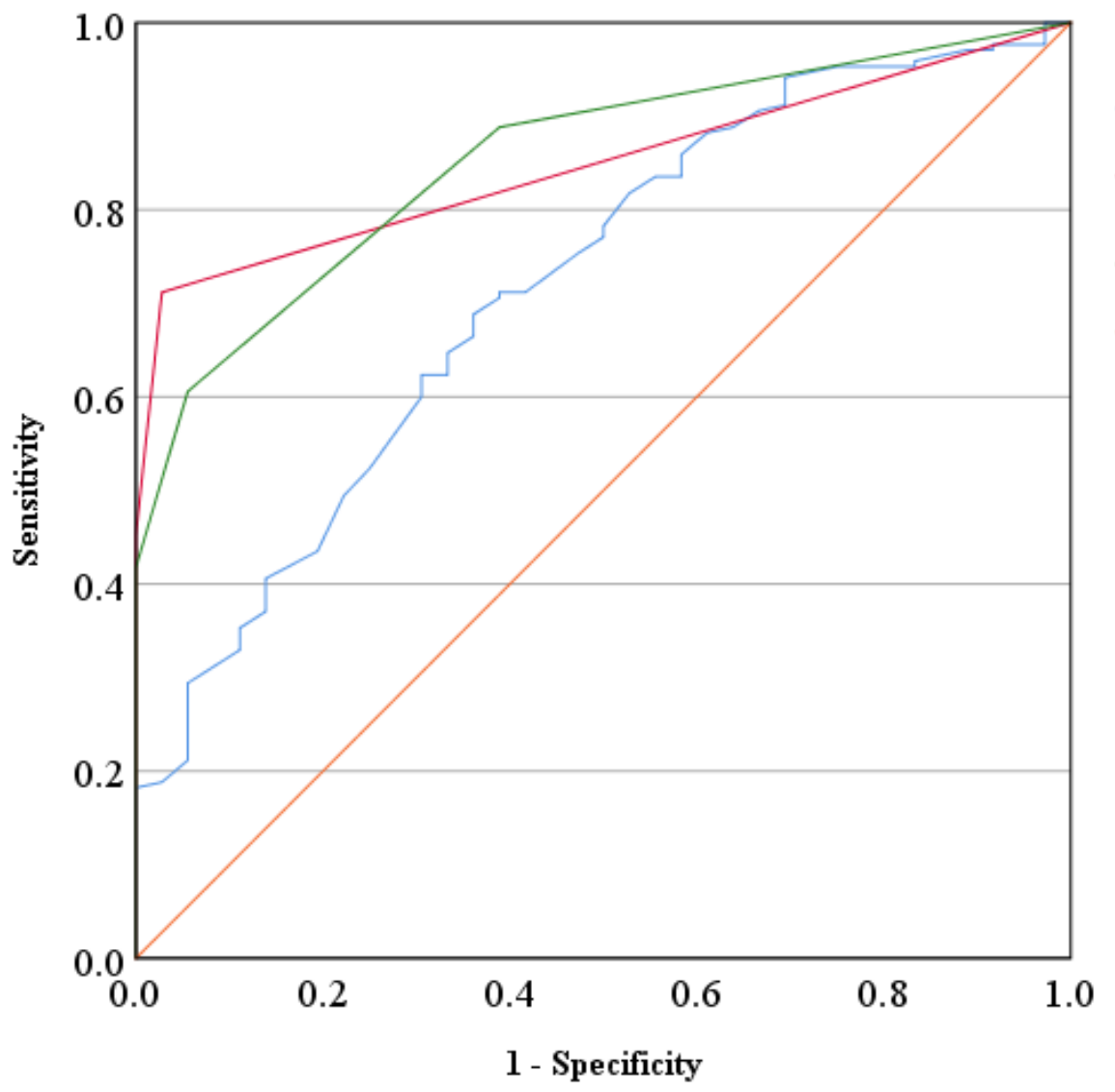

Source of the Curve

IGF Child-Pugh score Child-Pugh-IGF combination

Reference Line

\section{Figure 1}

Roc curve for IGF-1, CTP score and their combination in differentiating liver cirrhosis. 